\title{
Corn Performance with Late Sowing in Planalto Catarinense, Brazil, Simulated with CERES-Maize Model
}

\author{
Célio Orli Cardoso ${ }^{1 *}$ and Olívio José Soccol ${ }^{1}$ \\ ${ }^{1}$ Departamento de Engenharia Rural; CAV; Universidade do Estado de Santa Catarina; C.P.: 281; 88520-000; \\ Lages - SC - Brasil
}

\begin{abstract}
This work had the objective to investigate the delay effects in the sowing date on corn establishment, cycle duration and yield through the computer simulations using CERES-Maize model, in order to help agrarian producers from the Mountainous Area of Santa Catarina, Brazil to take better decisions on it. The computer simulations showed that: 1)the risks on corn establishment increased due to the delay of sowing during the studied years; 2) in some years, its cycles were drastically affected for the lower temperatures; 3) the cycle durations were longer when confronted with the low temperatures; 4) corn income decreased when the cycles were confronted with the low temperatures, water deficiency and low solar radiation; 5) potential incomes averaged $4944 \mathrm{~kg} \mathrm{ha}{ }^{-1}$, and under the natural rain conditions averaged $2490 \mathrm{~kg} \mathrm{ha}^{-1}$, during all the months analyzed from October to March; 6) besides January, the exploration of this cultivar was not viable because of the high risk of the crop frustration associated to the same ones, due to the thermal conditions (low temperatures and frost).
\end{abstract}

Key words: Simulation, Mathematical Model, Sowing date

\section{INTRODUCTION}

The choice of the corn sowing season is an important management decision that influences the yield of this cultivar, being conditioned mainly by the water and thermal conditions of the soil during the sowing. It is a critical management decision taken by the farmers annually, because the temporary displacement of the sowing means the corn cultivation in a not recommended period, under not favorable climatic conditions, a larger risk of the current frustrations due to adversities, alterations in the cultivar behavior in terms of phenological, physiological stresses and reduction on the production potential and others (Sans and Santos, 1992).

According to Almeida et al. (2000), Argenta et al. (2001) and Sangoi et al. (2001), the sowing time and the length of the growth period also influenced the choice of the corn plant arrangement (density and cycle duration) and the variability among the plants. In the early sowing (ending of winter and beginning of the spring), particularly in the temperate and sub-tropical areas, larger densities of the plants are requested (Almeida et al., 2000). In these cases, the lower atmospheric temperatures and the smallest readiness of the solar radiation have restricted the foliar expansion and the culture height, hence increasing the number of the plants

*Author for correspondence 
in order to optimize the efficiency of solar radiation use (Sangoi et al., 2001). That is larger population of the plants to optimize the grain revenue, because of its smallest number of the leaves, smaller foliar area and smaller plants height. The three aspects, early sowing, the use of less vigorous seeds and the variation of sowing deep, have increased the variability among the plants because of their influence on the speed of the plants emergence and due to the lower soil temperature.

The mountainous area of Santa Catarina is characterized by showing a period of shortsummer growing due to peculiar climatic conditions, mainly thermal characteristics, with a strong winter and a pleasant summer, sometimes oscillating with high temperatures, a factor which influences the agricultural exploration of the area. Consequently, corn productivity in this area strongly depends on the sowing period. The latter the sowing, the most intense production decreases with the larger risk of loss (Sangoi, 1993; Dias et al., 1997) due to the low temperatures, frosts and prolonged periods of the dry weather, mainly when these happen at the time of flowering stages and grain formation.

From the experiments in loco in Lages/Santa Catarina, Sangoi (1993) obtained the best income with the corn sowed from the middle of September to the middle of November. It was observed that when the sowing was delayed in relation to this period, the number of the spikes for the plant decreased, as well as the medium weight of grains formed by spike, which resulted in lower incomes. The period of corn exploration in late sowing in this area is frequently characterized by a gradual reduction of the pluvial precipitation and increase in the occurrence of the frosts. In these conditions, the crop success depends on the combination between the sowing season and the cultivar cycle, which facilitates the escape of the drought and frost periods (Gomes, 1995). For each area, risk studies have been conducted with larger success probability, that is, larger stability of the cultivar production.

According to Sangoi (1993) the Mountainous Area of Santa Catarina showed little flexibility on the choice of the sowing period for the corn cultivar due to its low thermal conditions, resulting in a season of shorter growing for the summer cultivars, when compared to other areas in Santa Catarina. According to Duarte et al. (1995), the thermal factor is the main limitation for the attributed to the smallest available solar radiation and to the smallest plant growth under the low development of the late sowing corn, and in some areas it is the water deficiency. Therefore, the possibility of frosts occurrence should be considered.

According to Sartori (1997) in summer, some ideal conditions for the development of the healthy corn are: during the sowing, the soil should have more than $10^{\circ} \mathrm{C}$ and humidity should be closed to the field capacity; during the growth and development of the plants, air temperature should be around $25^{\circ}$ $\mathrm{C}$ and an effective presence of the water in the soil. Favorable temperature and brightness, water resources and high relative humidity of the air are the basic requirements during the flowering and grains filling. With relation to the flowering and maturation, daily medium temperatures above $26^{\circ}$ $\mathrm{C}$ can promote the acceleration of these phases, but lower them $15.5^{\circ} \mathrm{C}$ can delay them quickly. The lower limit of the air temperature tolerated by the corn has been considered as approximately $10^{\circ}$ C (Gilmore and Rogers, 1958), but it could vary according to the genotype and phase of development (Berlato and Sutili, 1984).

Generally, the problems with the low temperatures are associated with the temperature effect on the vegetative development (fecundation and grain filling period) and not with the germination and the initial plant development. As the corn sowing occurs in the summer or in the beginning of the fall, usually the soil temperature is not a restrictive factor for the germination and initial development of the culture (Miranda Filho, 1995). According to Argenta et al. (2001), the determination of the corn seed potential revenue in different areas under different control systems, is an important tool for decision taken on the cultivar management, making possible the identification of the limiting factors. Thus, it is possible to define the strategies on how to surpass or minimize those restrictive factors to the revenue through an appropriate handling of the plant and environmental conditions. The combination of these two factors can maximize the exploration of the resources in each environment and optimize the productivity of the agricultural specimens in a sustainable manner. The impossibility of controlling and manipulating the environmental factors makes difficult the study of their effects with the traditional experiments. Hence, the use of the simulation models has been looked with the objective of helping to take the best decisions on its management. Studies have 
demonstrated the validity of the growth culture models in order to study the effects of the evaluate the appropriate management (Bernardo et al., 1988; Rogers and Elliot, 1989; Gedaken, 1998; Soler, 2000; Cardoso et al. 2001, 2004; Freitas et al., 2001, 2004), and others. The success of the cultures management is associated to the ability to be integrated data from a range of situations in a way that allows the profitable information for taking decisions. In this sense, the field experiments are laborious, expensive and delayed, therefore, the culture growth models are more appropriate and they are constituted in the best option of the decision analyses for the management. It is possible to find many simulation models of the growth for several cultures, whose economic importance and efficiency have been confirmed in several situations, CERES models for the grasses growth simulations, being denominating the CERESMaize. The "Crop-Environment Resource Synthesis (CERES) - Maize" model was elaborated by an interdisciplinary team from the Water and Soil Research Laboratory in Texas, United States (Jones and Kiniry, 1986), with the objective of quantifying the independent and interactive genotype effects, meteorological time, soil attributes and cultivation management practices in the growth and production of a specific cultivar. The model simulates the main physiological corn processes including the photosynthesis; respiration; biomass accumulation and partition; phenology; extension of the leaves, stems and roots growth; extraction of the soil water, evaporatranspiration and grains yield. The CERES-Maize is a mechanistic and deterministic model for the corn growth simulation and development by a physiological process with daily calculation.

The great importance of these models on decision taking is on its ability to analyze the practices from different ways of the management, simulating production, use of resources and risk associated to the analyzed management. According to Andrade Jr. et al. (2006), the use of the culture models demands less time, work and resources on decision taken in the agricultural sector, because it makes possible a preview of the process and/or a better understanding of the applied system.

This work had the objective to investigate the delay effects in sowing date on corn establishment, cycle duration and yield through the computer simulations using the CERES-Maize model, in environmental restrictions on the yield (Eagli and Bruenning, 1992; Cardoso et al., 2004), and to order to help producers from the Mountainous Area of Santa Catarina, Brazil to take better decisions on it.

\section{MATERIAL AND METHODS}

The analyses for the sowing periods and corn risks were accomplished from the long-term simulations (23 years) with the CERES-Maize model, previously gauged, in agreement with the information and procedures obtained from the EPAGRI and the available literature. The simulations were made for the municipal district of Lages (Latitude: $27^{\circ} 49^{\prime}$ South; Longitude: $50^{\circ} 20^{\prime}$ west, Altitude: $940 \mathrm{~m}$ above the sea level). Its climate is classified as subtropical humid, with soft summers $(\mathrm{Cfb})$, cold winter and rainfall well distributed during the whole year and occasional frosts from May to September. The climatic data were obtained from the meteorological station of EPAGRI, whose historical series of the registrations contains 23 years of observation (1980-2002). It is composed of daily registrations on rainfall, air temperature, solar radiation, relative air humidity, winds and potential evapotranspiration estimations with the PriestleTaylor equation. The soil data were obtained from the experimental tests from the Agroveterinary Science Center in a representative soil of the place studied, classified like Latossolo Roxo, Typic Haplorthox (EMBRAPA, 1999), and characterized by the clay contents around 50\%, deep profiles, high infiltration, level of underground water as absent or deep, and low organic content.

The corn genetic coefficients (cultivar XL-520) needed to the simulation application of CERESMaize model were obtained from the previous calibrations accomplished by Lima (1995) from the field test data with several sowing dates and water regimes. The management conditions followed the technical recommendations suggested for the corn in the studied area.

The corn sowing period included the months from October to March. In this study, the simulations were made for different sowing dates in intervals of 10 days, and they were considered as the treatments. A spacing of $0.9 \mathrm{~m}$ between the lines was adopted with 6.0 plants $\mathrm{m}^{-2}$, and nitrogen application of $20 \mathrm{~kg} \mathrm{ha}^{-1}$ during the sowing and 50 $\mathrm{kg} \mathrm{ha}{ }^{-1} 45$ days after the sowing (covering 
fertilization). Five days before each sowing date the incorporation of the residues from the antecedent culture, consisting in a total of $100 \mathrm{~kg}$ $\mathrm{ha}^{-1}$ of nitrogen was considered.

The simulations were processed considering two different matters: in the first one, for an ideal water condition, allowing to obtain the potential yields without water restrictions; in the second one, natural rain conditions (with possible water stress) was considered.

The model was validated previously by means of the quantitative data of the field tests developed with the specific objective, besides other data collected in the experiments including a quite wide range of the management and possible climatic conditions for the corn cultivation. A detailed description of the CERES-maize model can be found in Cardoso (2001).

\section{RESULTS AND DISCUSSION}

The number of the flaws for the corn establishment simulated with the base in several meteorological registrations, admitting sowings made in 18 ten-days period from October to March are shown in Fig. 1. A casual variation was observed in the flaws occurrence for the corn establishment, which were caused, mainly, for the unfavorable conditions of soil moisture to the seed germination. That fact happened at different times along the series of the years used in the simulations, that is, these flaws happened due to the low humidity (below 50\%) of the storage capacity along the whole ten-days period considered for the sowing, condition assumed as a criteria for the emergence. Besides, during the sowings in March, the low soil temperature also resulted in establishment flaws in some years. In Fig. 2, the functions of the accumulated probability of the cycles duration are presented for the sowing periods in each ten-days period from October to March (treatments). It was observed that the sowings from January provide larger cycle duration, due to the confront of its final phases with the conditions of low air temperature, reducing its growth and development rates. The sowings made from October to December showed smaller cycles, except in the years where the lower temperatures during the fall (precocious frosts) occurred.

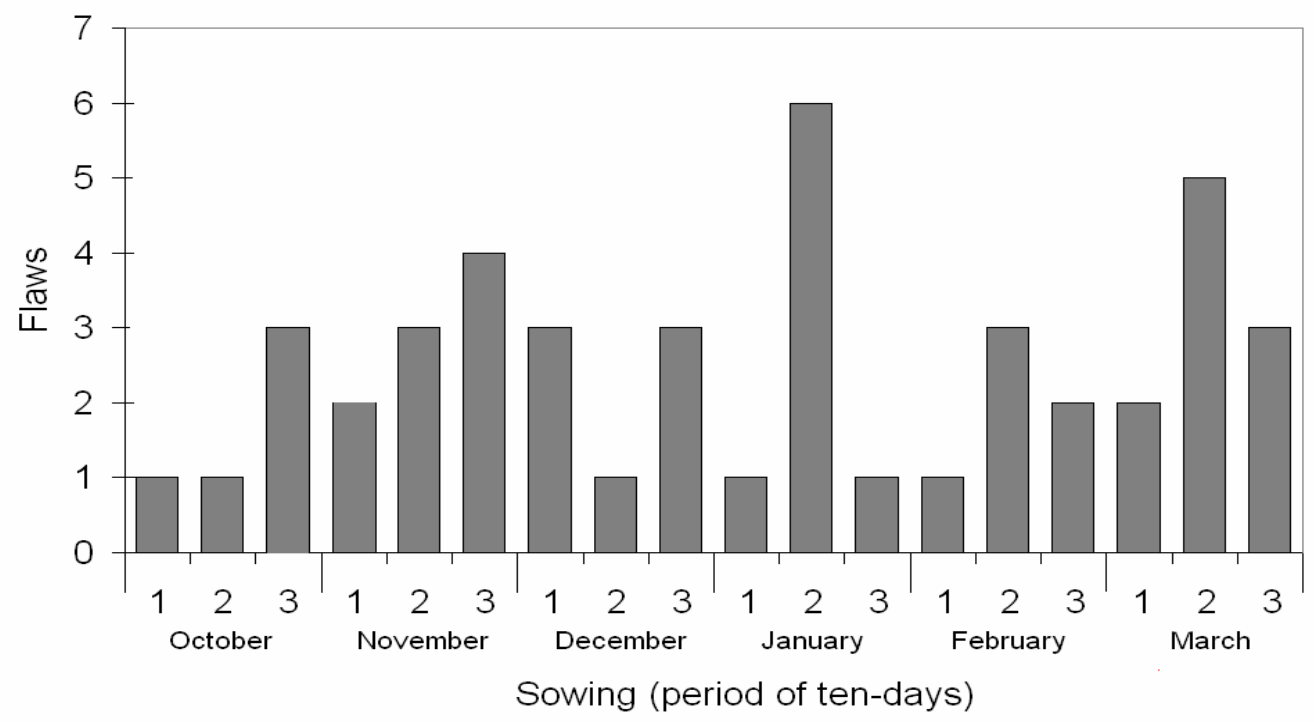

Figure 1 - Frequency of flaws in ten-days period in the corn establishment from October to March in 23 years of the simulations for Lages-SC. 

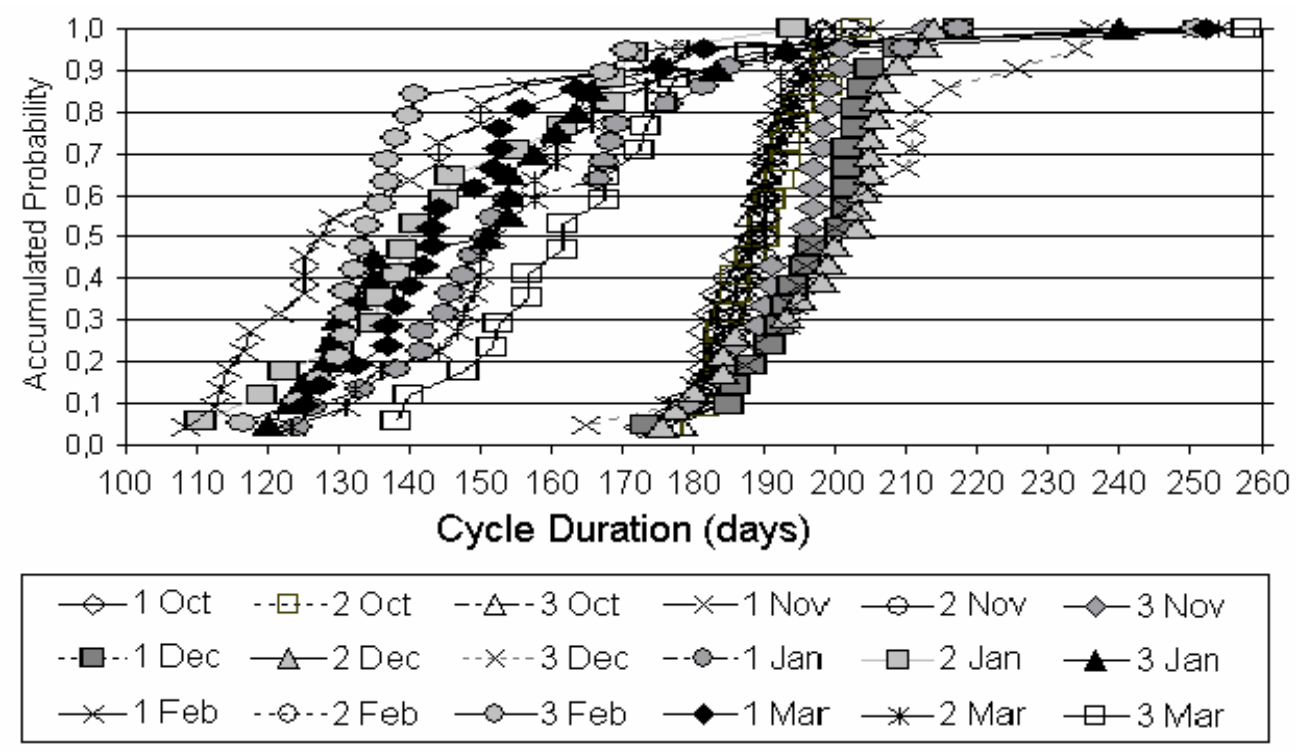

Figure 2 - Function of accumulated probability of the corn cycle duration from October to March in 23 years of the simulations for Lages-SC.

The medium cycles duration showed a tendency in increase when the sowing was late from the second ten-days of March, tending to decrease during the sowing after the first ten-days of April. This happened due to the confront of the cycle phases with the lower temperatures during the winter (longer cycle) or higher temperatures in the other seasons (shorter cycle).

Figure 3 showed that the duration of the sowinganthesis period, on average, tended to decrease when the sowing was late until the $2^{\circ}$ ten-days period of January, when it tended to increase gradually after the sowings. Similar results were obtained by Sangoi (1993) in experiments made during 1986/1987 and 1988/1989, when he observed that the duration of the emergence tasseling period of the studied cultivars was reduced substantially with the late sowing from September to December. This was due to the coincidence of the culture cycle phases with the higher temperatures, resulting in larger velocity in the processing of the metabolic reactions in the plant, which accelerated its cycle, mainly in that period between the emergence and tasseling. It was also noticed that the medium duration of the cycles were around 150 days in sowings during October to December and around 190 days for the sowings from January to March. Several researchers like Berlato et al. (1973) and Cardoso and Mundstock (1978) have demonstrated that the corn plant needed certain thermal sums in order to conclude each stage of its cycle. Thus, when the corn is sowed in a period, which provides a cycle with the higher temperatures, the culture accumulates the necessary thermal sums more quickly to its metabolism and, consequently, its development stages and its cycle will be shorter than when these coincide with the periods of the lower temperatures.

Without accentuated the water restrictions for the plant development, the most adequate period for the corn sowing was that one which coincided the flowering period and the beginning of the grains filling with the longest days and periods of the highest temperatures and solar radiation (Hatfield et al., 1965; Mundstock,1970 and Sutili et al., 1977).

Figure 4, showed the tendency of the gradual decreases in the potential yield as the sowing was later, until sowings made in March, showing more accentuated decrease from the sowings made in January. In sowing of the $1^{\circ}$ ten-days period in October, the 23 year-medium potential yield was $9220 \mathrm{~kg} \mathrm{ha}^{-1}$ decreasing by $250 \mathrm{~kg} \mathrm{ha}^{-1}$ in the sowings made in March. This yield decrease could be attributed to the lowest solar radiation during the autumn and winter periods and lower temperatures with the frost between the flowering 
and the physiological maturation, they determined the abrupt ending of the grains filling period because of their slow filling and low growth rates, which were influenced by the temperature. In these cases, the model concluded the cycle of the cultivar development in advance.

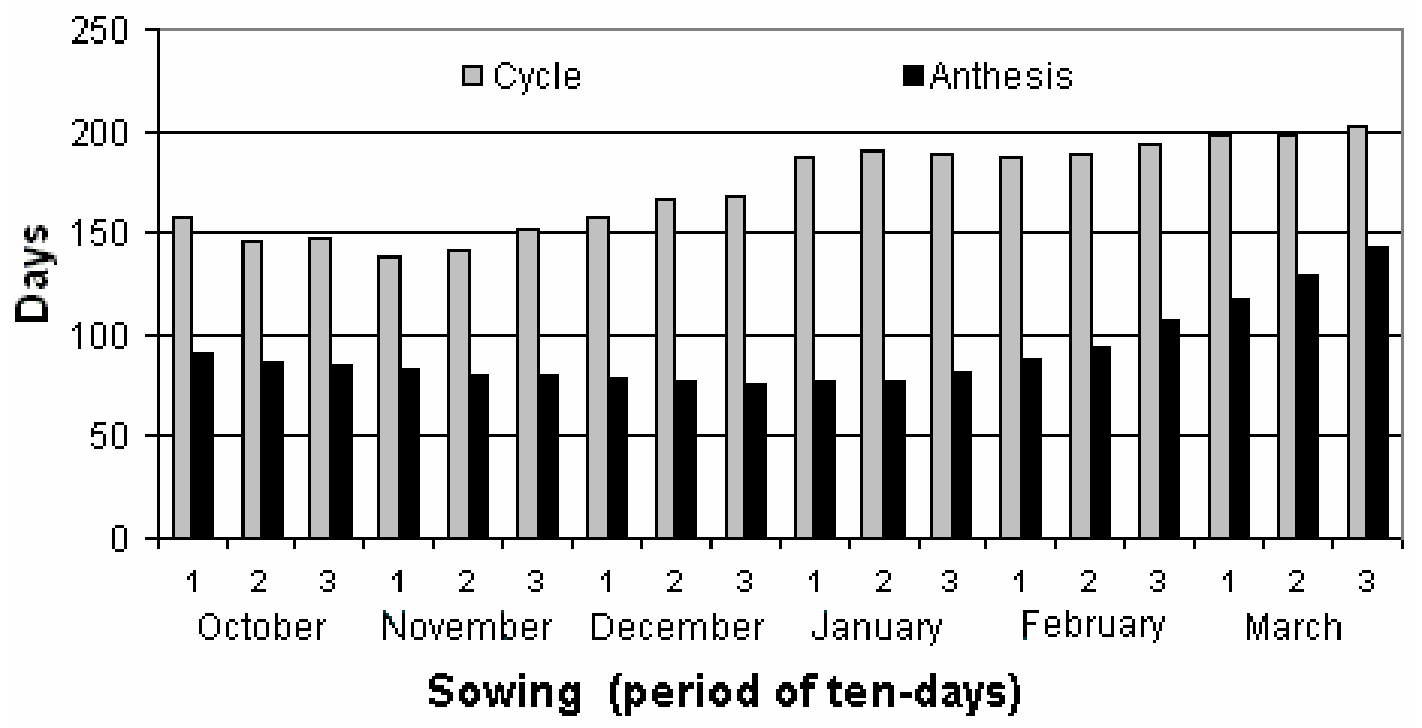

Figure 3 - Medium duration of anthesis and corn cycle from October to March in 23 years of simulations (1980-2002) for Lages-SC.

According to Sangoi (2001), the lowest thermal readiness and solar radiation could limit the photosynthetic activity of the leaves and the translocation of the assimilated vegetative fractions for the grains. The best yield obtained in the sowings simulations in October could be attributed to the coincidence of the most sensitive cultivar periods (flowering and grain formation) with more favorable conditions of the temperature, solar radiation and soil moisture, minimizing the cultivar stress. Sangoi (1993) pointed out that although it could present restrictions to the cultivation of summer species, the area of Lages also showed favorable climatic characteristics for the corn production. Among them, the most important was in the months of the spring and summer, accentuated problems the with water deficiency, which favored this cultivar that was quite sensitive to the water stress, especially during the tasseling - spiking stage (Denmead and Shaw 1960). It could be said that the water supply in this area, in most of the agricultural years, was an important characteristic. On the other hand, the low temperatures and largest number of the frosts during the late sowings resulted in a high number of frustrated crops and with the low solar radiation, they were responsible for the lowest yield.

The dark columns in Fig. 4 indicated the yield in the current scenario, considering the current losses of water stress and soil fertility (Nitrogen deficiency). It was observed that in the sowings from October to December, the yield with the stresses (real conditions) reached medium values around $3900 \mathrm{~kg} \mathrm{ha}^{-1}$, being less than the potential scenario yield. Thus, it would be imperative to define the management strategies on the irrigation and nitrogen fertilizers, minimizing the stresses, facilitating the optimization of the resources involved in the productive process in order to explore the whole genetic potential of the cultivar. Fig. 5 showed the curves of the accumulated probabilities for the medium potential yields of the corn, sowed in 18 ten-days period from October to March, obtained from 23 years-simulations for Lages, SC.

In general, the largest potential yields were obtained in the sowing of the $1^{\circ}$ ten-days period of October and the lowest ones resulted from the simulations with the sowing in the $1^{\circ}$ ten-days period of March. 


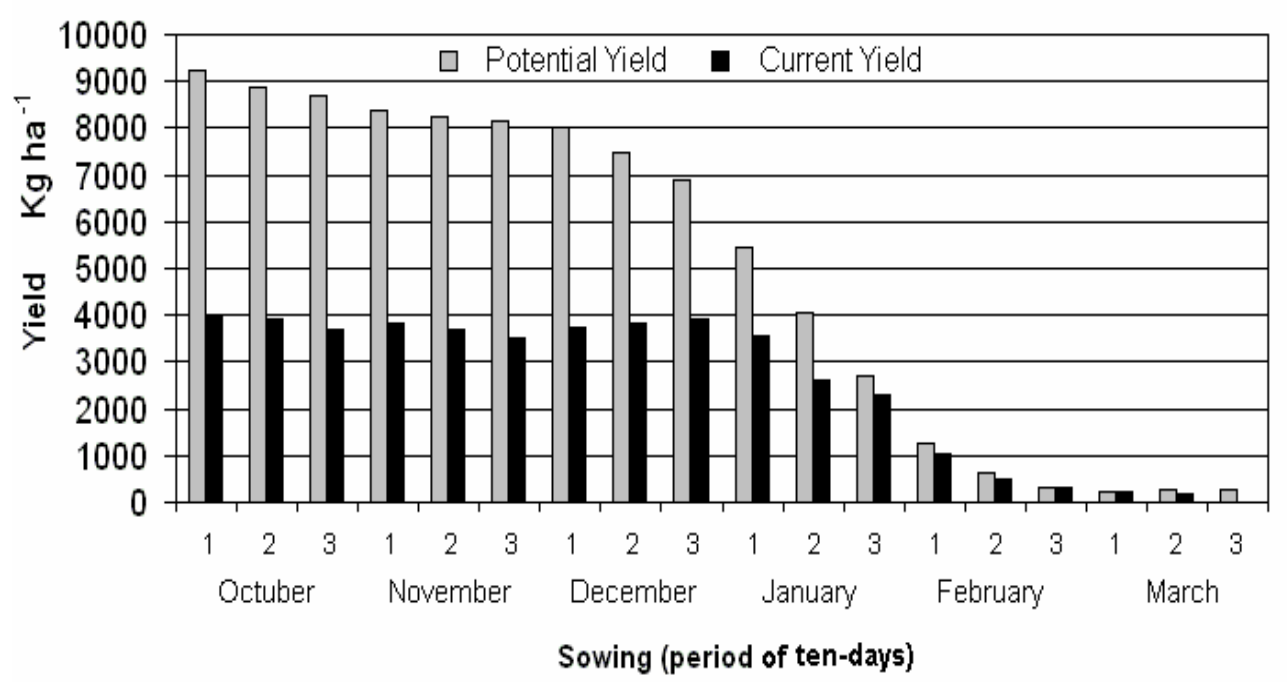

Figure 4 - Medium potential yield of the corn (cultivar XL-520) sowed in the period from October to March in Lages.

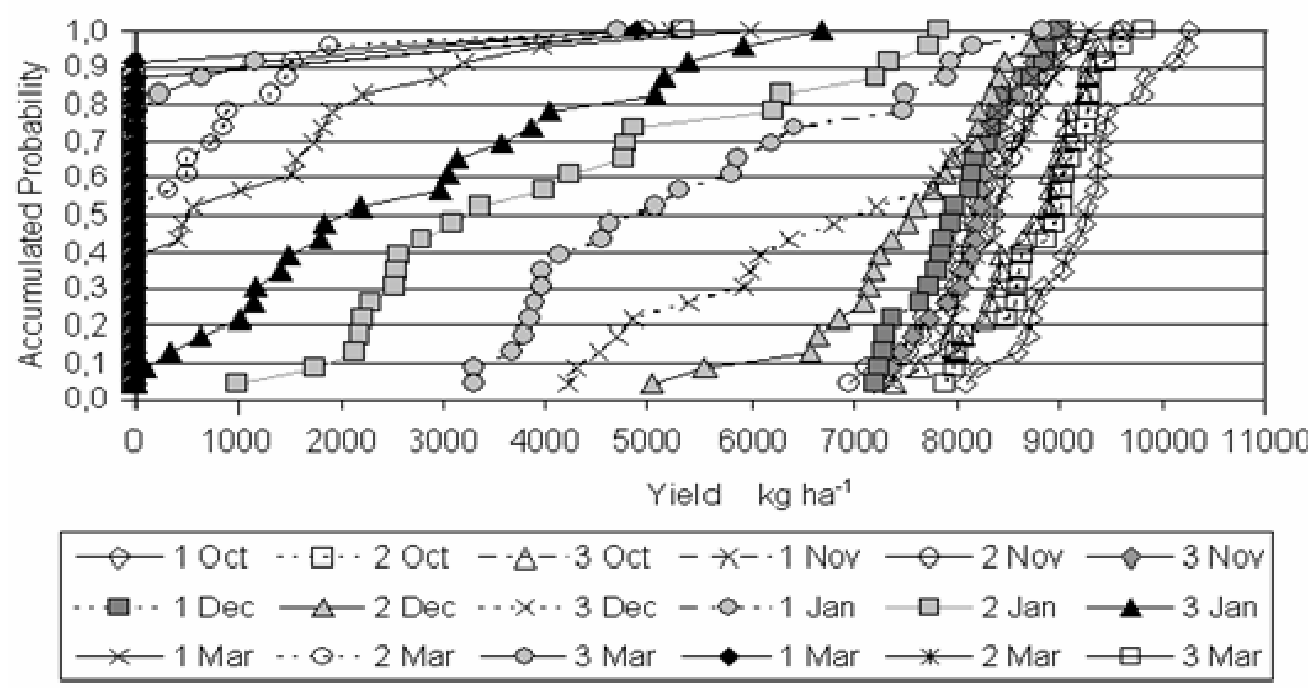

Figure 5 - Accumulated probabilities of the potential yield of the corn (cultivar XL-520) sowed from October to March in Lages/SC.

The high risks of crop frustrations was also observed in the sowings from the $3^{\circ}$ ten-days period of January. With $10 \%$ of the probability, it was possible to wait null potential medium yields in the sowings from the $1^{\circ}$ ten-days period of February. For the sowings after the $2^{\circ}$ ten-days period of February, the risk of the total crop losses was higher then $50 \%$, reaching $90 \%$ in the sowing was higher then $50 \%$, reaching $90 \%$ in the sowing of the $1^{\circ}$ ten-days of March.

In the situation with the temperature stresses and nitrogen fertilizers, the accumulated functions of probability presented in Fig. 6 was obtained.

Evidently, the larger risks in the potential scenery and in the $3^{\circ}$ ten-days period of March, $100 \%$ of 
the simulated crops presented the null yields. It was observed that the risks of the crop frustration (null yield) became significant from the $3^{\circ}$ ten-days period of January. The accumulated curves of the yield probability of the sowings from October to the $1^{\circ}$ ten-days period of January were quite the same, but the $3^{\circ}$ ten-days period of December presented $2^{\circ}$ degree stochastic dominance, therefore showing that it was the best sowing period for this cultivar in the stress conditions.

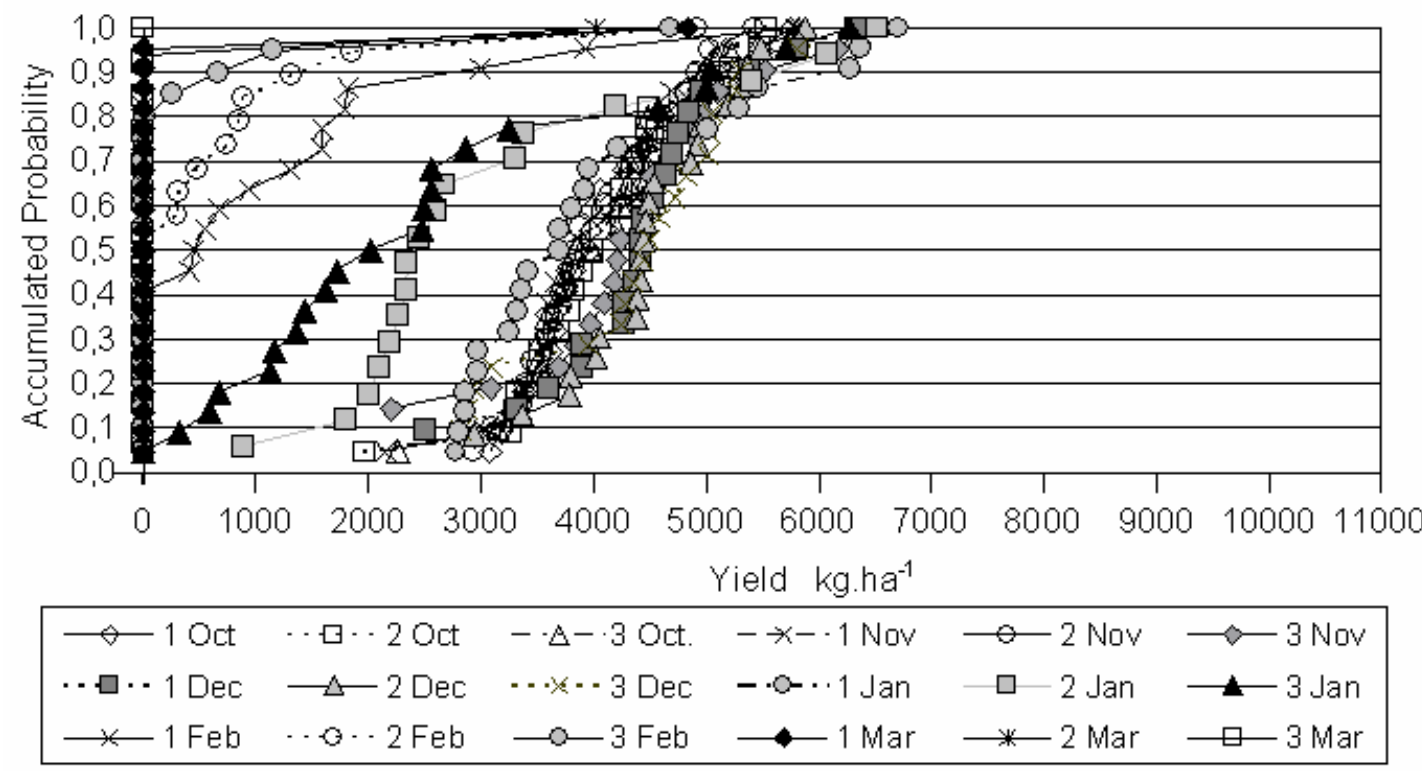

Figure 6 - Accumulated probabilities of the current yield of the corn (cultivar XL-520) sowed from October to March in Lages/SC.

The simulations for the corn cultivar with the CERES-maize model and cultivar XL-520 of the precocious cycle allowed to conclude that:

- The risks of the corn establishment were very variable during the analyzed ten-days periods, the humidity condition was the most important factor; - In some years the cycles were drastically affected due to the low temperatures;

- The duration of the cycles tended to prolong when confronted with the low temperatures;

- The potential yields were on average $4944 \mathrm{~kg} \mathrm{ha}$

1 and in the natural rain conditions, with the water stress and nitrogen, on average $2490 \mathrm{~kg} \mathrm{ha}^{-1}$, considering the whole analyzed period from October to March;

- The exploration of this cultivar, besides January, was not viable due to the high risk of the crop frustrations associated to the same, because of the thermal conditions (low temperatures and frosts).

\section{RESUMO}

O trabalho teve como objetivo investigar os efeitos decorrentes do atraso da semeadura no estabelecimento, duração do ciclo e rendimento do milho, mediante simulações em computador com o uso do modelo CERES-Maize, a fim de orientar os produtores na tomada de decisão na região do Planalto Serrano Catarinense. Em função da época em que é cultivado, o milho com semeadura tardia normalmente está exposto a riscos maiores de perdas por geadas e deficiência hídrica em relação ao cultivo na época recomendada, atingindo um menor potencial de produtividade e tendência de alongamento do ciclo. As simulações permitiram concluir que: os riscos de estabelecimento do milho foram bastante variáveis ao longo dos decêndios analisados; em alguns anos os ciclos foram afetados drasticamente por temperaturas 
bastante baixas; as durações dos ciclos tenderam a alongar-se quando confrontados com temperaturas baixas; os rendimentos decresceram quando os ciclos se confrontaram com temperaturas baixas, menor disponibilidade hídrica e de radiação solar; os rendimentos potenciais foram em média de $4944 \mathrm{~kg} \mathrm{ha}^{-1}$ e em condições de chuva natural de $2490 \mathrm{~kg} \mathrm{ha}{ }^{-1}$, considerando todo o período analisado (outubro a março); a exploração desta cultivar, além do mês de janeiro não seria viável devido ao alto risco de frustrações de safras associadas às mesmas, decorrentes das condições térmicas (temperaturas baixas e geadas).

\section{REFERENCES}

Andrade Jr., A.S.; Figueredo Jr., L.G.M.; Cardoso, M.J.; Ribeiro, V.Q. (2006). Parametrização de modelos agrometeorológicos para estimativa da produtividade da cultura do milho na região de Parnaíba, Piauí. Revista Ciência Agronômica, 37 (2), 130-134.

Almeida, M.L.; Merotto Jr., A.; Sangoi, L.; Ender, M.; Guidolin, A.F. (2000). Incremento na densidade de plantas: uma alternativa para aumentar o rendimento de grãos de milho em regiões de curta estação estival de crescimento. Revista Ciência Rural, 30, 23-29.

Argenta, G.; Silva, P. R. F.; Sangoi, L. (2001). Arranjo de plantas em milho: Análise do estado-da-arte. Ciência Rural, Santa Maria, 31(6), 1075-1084.

Bernardo, D.J.; Whittlesey, N.K.; Saxton, K.E.; Basset, D.L. Irrigation optimization under limited water supply. Transactions of the ASAE, 31, 712-719.

Berlato, M.A.; Sutili, V. (1984), Relação entre temperaturas e o aparecimento de fases fenológicas do milho (Zea mays L.). Agronomia Sulriograndense, 20, 111-32.

Berlato, M. A.; Sutili, V.; Castro, A. O. (1973), Comparação de 3 métodos de cálculo da exigências térmicas para o espigamento do milho (Zea mays, L.). Agronomia Sulriograndense, Porto Alegre, 10 (1), 87-94.

Cardoso, C.O. (2001), Análise de riscos climáticos e estratégias de irrigação para o milho "safrinha" no Paraná, através de modelos de simulação. Piracicaba, 114 p. Tese (Doutorado) - ESALQ/USP.

Cardoso, C. O.; Faria, R. T.; Folegatti.(2004) Simulação do rendimento e riscos climáticos para o milho safrinha em Londrina, PR, utilizando o modelo CERES-Maize. Engenharia Agrícola, Jaboticabal, 24 (1).
Cardoso, C. O.; Faria, R. T.; Folegatti. (2004), Aplicação do modelo CERES-maize na análise de estratégias de irrigação para milho "safrinha" em Londrina-PR. Engenharia Agrícola, Jaboticabal, 24 (1).

Cardoso, M.J. Mundstock, C.M. (1978), Comparação de treze métodos de cálculo de unidades térmicas de desenvolvimento de milho (Zea mays L.). Ciência e Cultura, 31, 1278-83.

Dias, H.S.; Balhestero, J.A.V.; Vetullo, D. and Gutierrez, L.S.D. (1997), Época da semeadura do milho "safrinha" em função da colheita da soja. In: Seminário sobre a cultura do milho "safrinha", 4., Londrina. Resumos. pp.57-60.

Duarte, A.P.; Kanthack, R.A.D.; Spinosa, W.; Alliparndini, L.F. (1995), Efeito da geada na produção e qualidade de grãos de milho. III Seminário sobre a Cultura do Milho "Safrinha". Assis, São Paulo. pp. 61-64.

Eagli, D.B.; Bruenning, L. (1992), Planting date and soybean yield: evaluation of environmental effects with a crop simulation model: SOYGRO. Agricultural and Forest Meteorology, 62, 19-29.

EMBRAPA. Centro Nacional de Pesquisa de Solos. (1999), Sistema brasileiro de classificação de solos. Rio de Janeiro: Embrapa, CNPS, 412p.

Freitas, P. S. L.; Mantovani, E. C.; Sediyama, G. C.; Costa, L. C. Penalização da produtividade da cultura milho imposta pelo modelo CERES-Maize. Acta Scientiarum Agronomy. Maringá, 27, n.1, p. 97-105, 2005.

Freitas, P. S. L.; Mantovani, E. C.; Sediyama, G. C.; Costa, L. C. (2004), Simulação da produtividade do milho pelo modelo CERES-Maize em função da lamina e da uniformidade de aplicação da água. Revista Brasileira de Engenharia Agrícola $e$ Ambiental, Campina Grande, 8 (.2), 225-232.

Gedaken, A. (1998), Utilização do modelo CERESMaize para avaliar estratégias de irrigação em duas regiões de Minas Gerais. (Dissertação de Mestrado) Universidade Federal de Viçosa, Viçosa.

Gilmore, E.C. and Rogers, J.S., (1958), Heat units as a method of measuring maturity in Corn. Agronomy Journal, Madison, 50, 611-5.

Gomes, J. (1995), Estudos de risco para o milho "safrinha". III Seminário sobre a Cultura do Milho "Safrinha”. Assis, São Paulo. pp. 111-113.

Hatfield, A.L.; Benoit, G.R.; Ragland, J.L. (1965), The growth and yield of corn. IV: Environmental effects on grain yield components of mature ears. Agronomy Journal, Madison, 57, 293-96. 
Jones, C.A. and Kiniry, J.R., (1986), CERES-Maize: A simulation model of maize growth and development. Texas AandM Univ. Press., College Station, TX. $194 p$.

Lima, M.G. (1995), Calibração e validação do modelo CERES-Maize em condições tropicais do Brasil. Piracicaba, 119 p. Tese (Doutorado) - ESALQ/USP.

Miranda Filho, J. B.. (1995), Melhoramento do milho visando à tolerância ao frio. III Seminário sobre a Cultura do Milho "Safrinha”. Assis, São Paulo, pp. 49-58.

Mundstock, C.M. (1970), Influência da época de semeadura em seis cultivares de milho (Zea mays L.). Porto Alegre: UFRGS - Fac. Agronomia, 69p. Dissertação de Mestrado.

Rogers, D.H.: Elliot, R.L. (1989), Irrigation scheduling using crop growth simulation, risk analysis, and weather forecast. Transactions of the ASAE, 32, 1669-1677.

Sangoi, L. (1993), Aptidão dos campos de Lages (SC) para produção de milho em diferentes épocas de semeadura. Pesquisa Agropecuária Brasileira, 28, 51-63.

Sangoi, L.; Almeida, M.L.; Lech, V. A.; Gracietti, L. C.; Rampazzo, C. (2001), Desempenho de híbridos de milho com ciclos contrastantes em função da desfolha e da população de plantas. Scientia Agrícola, 58 (2) 271-276.
Sangoi, L. (2001) Understanding plant density effects on mayze growth and development: an important issue to maximize grain yield. Ciencia Rural, Santa Maria, 31(2).

Sans, L.M.A. and Santos, N.C. (1992), Resposta de cultivares de milho a variações climáticas. Congresso Nacional de Milho e Sorgo, 19., Porto Alegre.

Sartori, J.S. (1997), Determinantes genético fisiológicos e elementos de manejo na escolha de cultivares de milho "safrinha". III Seminário sobre a Cultura do Milho "Safrinha". Assis, São Paulo.

Soler, C. T. (2000), Uso do modelo CERES-Maize para identificação de características genéticas desejáveis para o milho "safrinha" e determinação de práticas adequadas de manejo em condições de risco climático. 86 p. Dissertação (Mestrado em Agronomia) - Escola Superior de Agricultura Luiz de Queiroz, Piracicaba.

Sutili, V.; Matzenauer, R.; Berlato, M.A.; Coelho, M.; Tedesco, (1977), A. Efeitos de épocas de semeadura no rendimento de grãos de três cultivares de milho em três regiões do Rio Grande do Sul. In: Reunião Técnica anual do milho, 22., Porto Alegre, Ata... Porto Alegre: IPAGRO,p p.39-54. 